\title{
The effect of multicultural attitude, learning style, and parents' job on the learning achievement of the students
}

\author{
Ratrining Raras Irawati * ${ }^{\text {, Zamroni Zamroni }}{ }^{2}$ \\ ${ }^{1}$ Sekolah Tinggi Agama Islam Al Husain Magelang. \\ Jl. Ir. Sutami No.36, Kentingan, Jebres, Surakarta, Jawa Tengah 57126, Indonesia. \\ ${ }^{2}$ Universitas Negeri Yogyakarta \\ Jl. Colombo No. 1, Karang Malang, Caturtunggal, Depok, Sleman, Yogyakarta 55281, Indonesia. \\ ratrining@gmail.com \\ * Corresponding Author
}

\section{ARTICLE INFO}

\section{Article History}

Received:

28 July 2019;

Revised:

30 January 2020;

Accepted:

1 January 2021

\section{Keywords}

Learning achievement;

Learning style;

Multicultural attitude;

Parents' job;

\begin{abstract}
The purpose of this research is to reveal the effect of multicultural attitude, learning style, and parents' job on the learning achievement of the students of senior high school in Magelang City, either partial or simultaneous. The research population was 771 grade XI students of social science of senior high schools in Magelang City, Indonesia, with a sample of 277 students. A multicultural attitude, learning style, and parents' job data were collected using questionnaires. In contrast, the economics learning achievement data were collected through an achievement test. The data were analyzed using multiple regression techniques. The study concludes that a multicultural attitude and parents' job positively affect economics learning achievement. But the learning style does not affect economic learning achievement. The multicultural attitude, learning style, and parents' job simultaneously affect the students of senior high school's economics learning achievement in Magelang City with a contributed of $5.1 \%$.
\end{abstract}

This is an open access article under the $\underline{\mathrm{CC}-\mathrm{BY}-\mathrm{SA}}$ license.

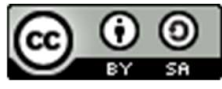

\section{INTRODUCTION}

Today's increasingly competitive world conditions have made people aware of education's importance, especially for people in developing countries like Indonesia. Education plays an essential role in advancing the progress of a nation. The Indonesian government also has a concern for education for the Indonesian people. This form of government attention can be seen through existing policies. Some of these policies are in the form of School Operational Assistance (BOS), construction of educational facilities in developing and repairing school buildings, revamping the curriculum, providing scholarships for high achieving students and underprivileged students, providing certification allowances for teachers, and many more. The policies that have been issued by the government have yielded results. The School Participation Rate (APS) in Central Java Province has increased. However, the APS figure in Central Java Province is still in the second-lowest position on Java, namely 67.66\% in 2015. Magelang City, located in Central Java Province, is a city with quite good learning achievements. Schools in Magelang City have made several achievements. For three consecutive years, the highest national exam score winner in the Central Java Provision came from Magelang.

Even though he achieved the highest national exam score in Central Java, it turns out that the average national examination score for economics subject to obtain still fluctuates every year. Compared with the average national exam score for the economy at the federal level, students' 
average score from SMA Negeri in Magelang City is already above the average national-level national exam score of all public schools in Indonesia. The average national exam score of private high school students in Magelang is still below the national average of all private high schools in Indonesia. Seeing the average national exam scores for economic subjects that are always fluctuating, it is suspected that several factors affect financial learning achievement in Magelang City. According to Syah (2013, p. 132), globally, the factors that influence learning achievement consist of: 1.) Internal factors, namely physiological factors and psychological factors; 2.) External factors, namely social and environmental environments non-social; as well as 3.) Learning approach factors. A student who is accustomed to applying a deep learning approach, for example, may have the opportunity to influence quality learning achievement than students who use a surface or reproductive learning approach. In Magelang City, it is suspected that three factors influence high school students' economic learning achievement. The first factor that is thought to affect financial learning achievement is the multicultural attitude of high school students in Magelang City. From research conducted by Separsa, Lasmawan, and Suarni $(2014$, p. 10), it was found that $23.23 \%$ of students' multicultural attitudes contributed to student achievement. Magelang City is one of the cities in Indonesia, which has a multicultural environment. The existence of a Military Academy campus in Magelang City, which brings people from all over Indonesia, adds to multiculturalism.

A multicultural environment can be defined as an environment consisting of various ethnicities, cultures, religions, and customs that gather in a particular area. Etymologically the term multiculturalism comes from the word multi (many) -culture (culture) -ism (views-ideas) or plural cultural ideology and as opposed to monoculturalism or a single cultural ideology. Brandt (from Billings \& Gillborn, 2004) says that multiculturalism focused on key terms that shared a rather distant and liberal character, such as monoculturalism or ethnicism, culture, equality, prejudice, misunderstanding, and ignorance monoculturalism or ethnicized as providing information and increasing awareness. By realizing that there is much diversity in the community environment in Magelang City, multiculturalism can be used as a bridge to existing differences. The role of Multiculturalism is vital because individuals experience cultural conflict when they subscribe to or live by two different systems of meaning and significance either wholly or partially (Parekh, 2000, p. 149). In essence, Multiculturalism contains recognition of humans' dignity who live in their communities with the culture owned by each organization to avoid conflicts in society.

According to Banks (2009, p. 35), multiculturalists have responded to this critique from both within and without by acknowledging more directly the role of unequal power relations and the inequalities and differential effects that ensue from them. This is not without reason because a multicultural society is very prone to conflict due to differences. A community cannot be in a state of peace forever without problems because it is from the issues that life dynamics will emerge. According to Zamroni (2011, p. 31), a multicultural society is a reality. Almost no society is monocultural. Knowles and Lander (2011, p. 66) say it's important to consider when discussing diversity, equality and achievement is that, while individuals can be deemed as belonging to specific groups because of their gender or ethnicit. With the diversity in the surrounding environment, it is necessary to have tolerance, which ced in a multicultural attitude. Not only within the general public, but multiculturalism also occurs in the school environment. Cruickshank, Jenkins, and Metcalf (2014, p. 67) argue that student diversity is a fact of life in all schools and classes we teach. This diversity can undoubtedly have a positive and negative impact on students. According to Braster and Dronkers (2013, p. 4) and Dronkers, Van der Velden, and Dunne (2010, 73), greater diversity of school populations means that diverse schools have more students whose capabilities and potentially differ from one another. The following mechanisms could, therefore, create a positive effect of diversity on individual educational performances: 1.) In more diverse schools, good students may help weaker fellow students by giving real help or setting an example; 2.) More vulnerable students have a greater chance of encountering a challenging curriculum in more diverse schools because the teachers teach such subject matter to the better students; and 3.) More capable students in more diverse schools also learn better themselves because they explain the subject matter to weaker students.

Meanwhile, Maruyama, Moreno, Gudeman, and Marin (2000, p. 14) found that classroom diversity broadened the range of perspectives shared in classes, exposed students to different 
perspectives, and encouraged students to confront a range of stereotypes, including racial, ethnic, social, political, and personal experience. So it is important to pay attention to the multicultural attitudes in the school and classroom environment. A multicultural attitude is an emotional combination of knowledge and belief and actions that reflect both. Also, with a multicultural attitude, it will be something that can bring benefits to students, both in the social environment of the school and society. Banks (2007, p. 26) also expressed the importance of a multicultural attitude, students must acquire higher levels of knowledge, understand the relationship between knowledge and action, develop a commitment to act to improve the world, and acquire the skills needed to participate in civic action so that with an excellent multicultural attitude, students are expected to be smart not only in science but also wise in relationships in society. Multicultural attitudes should be cultivated in students from an early age, starting from the family and school environment. The multicultural attitude of students can be seen through: 1.) Awareness and understanding of diversity; 2.) Commitment and personal involvement in social life; 3 .) Responsibility is doing something for the common interest; 4.) Skills in collaboration and solving common problems; and 5.) The nature of openness and skills (Zamroni, 2011, 35) possessed by students.

Even so, research conducted by Marrison and Frick from Purdue University, United States entitled The effect of agricultural students' learning styles on academic achievement and their perceptions of two methods of instruction did not find a significant influence between student learning styles and learning achievement. Unfortunately, in this research, it is not explained with certainty why learning styles do not have a substantial effect on student achievement. However, the provisional assumption is that the development of multimedia technology used in learning achievement tests is so fast that it can affect this study's results. Another factor that can affect student achievement is parental work. According to the Ministry of Manpower and Transmigration of the Republic of Indonesia (2013, p. 2), work is an economic activity carried out by a person to obtain income or profit for at least 1 hour (uninterrupted) a week ago. This activity includes activities of unpaid workers who assist in an economical business or training. Hassan $(2009$, p. 31) said parental employment expects to have considerable effects on their children's welfare. Concerning the children's educational achievement, parental engagement might have two contradicting effects. Parents play a significant role in children's education (Gu, Yin, \& Li, 2015). Parents' role in education is to assist their children (Bernal, Urpí, Rivas, \& Repáraz, 2011). Research conducted by Arshad, Shahzadi, and Mahmood (2016) shows that parents cause parents' spirit. Mendel (2020) explained that the spirit of parents given would make their children successful. According to Dusi (2020), the relationship between parents and children is maintained so that children feel cared for.

On the other hand, having a source of income is essential for meeting children's educational needs and participating in social activities. From this, it is clear that parents' work is expected to produce welfare for the children (students) to meet the children's educational needs. The role of parents is essential for the learning progress that will be achieved by a child in the future. It is from the parents that the child's first motivation to learn to obtain. When parents do not support children, then a child does not have the reason to know either. Apart from giving psychological support, parents also play a role in providing material support to children. This material support can be provided in the form of providing learning aids. According to Hamalik (2013, p. 51), learning aids are all tools that can be used to help students do learning actions so that learning activities become more effective and efficient. The provision of study aids here can include books, stationery, tutoring, electronic learning media, and much more.

All of this will be achieved if parents provide welfare to children in learning facilities obtained if the parents have jobs with stable income. One of the jobs that have a steady income is working as a civil servant. In Indonesia, civil servants are regulated in legislation, namely in Law of the Republic of Indonesia Number 43 of 1999 concerning employment principles. In Law of the Republic of Indonesia Number 43 Article 1 of 1999, a civil servant is every citizen of the Republic of Indonesia who has met the specified requirements, is appointed by an authorized official and assigned to a state office or assigned to other state duties, and is paid according to the prevailing laws and regulations. The division of civil servants' types and positions is also regulated in Article 2, namely civil servants consisting of Civil Servants (PNS), members of the Indonesian National Army (TNI), and Republic Indonesia members.

Volume 7, No. 2, September 2020 
Hassan (2009, p. 34) found a positive relationship between parental work and student achievement. However, parental work on student achievement is not limited to meeting children's educational needs. As Berns (2010, p. 122) stated, middle-class occupations (such as a teacher or office manager) typically require the individual to handle ideas and symbols and be skilled in dealing with interpersonal relations. In contrast, lower-class occupations (such as construction workers or janitors) typically involve physical objects rather than characters and do not include many interpersonal skills. With these characteristics, generally causes, middle-class parents emphasize more self-direction for the child; lower-class parents emphasize more conformity (Berns, 2010, p. 123). Parents' work significantly affects student achievement in school because parents who have middle-class jobs such as teachers or managers usually pay attention to their children's learning patterns to support their school success. Vice versa, parents with lower-class jobs such as laborers, will pay less attention to learning practices. His child and will give the child's education to school.

In contrast, parents who ignore their children's education can cause their children not / less successful in learning (Slameto, 2013, p. 61). However, in addition to material attention from parents, emotional attention is also needed by students. In contrast to previous research that proved a significant influence between parents and student achievement, Abosede's (2015) study entitled gender, parents job type, and family size as determinants of junior secondary school students' academic performance had insignificant results. According to Abosede (2015), although parents' work can help provide financial support, namely providing adequate learning facilities, this will not mean anything. The higher the level of work the parents have, it will reduce the time for parents to interact with their children (for example, parents cannot accompany children in studying), so that the level of work of parents will not significantly affect the achievement of learning achievement in children because of lack of emotional support.

By looking at the existing problems, the purpose of this study is to determine the effect of multicultural attitudes, learning styles, and parents' work on the economic learning achievement of high school students in Magelang City both partially and simultaneously. What is meant by financial learning achievement here is student learning achievement in studying economics subjects at school. Economic learning achievement assessment is carried out to assess cognitive aspects by looking at the total value achieved by students in doing achievement tests in written tests. The multicultural attitude in this study is students' attitude in realizing and responding to the multicultural environment that exists in school. Collecting data or information about multicultural attitudes refers to and develops The Munroe Multicultural Attitude Scale Questionnaire. While what is meant by the learning style in this study is the way students have in learning, it reflects these students' characteristics. To measure this learning style, researchers developed a questionnaire that has been compiled by Bobbi dePorter, Readen Park, and Sarah Singer Nouri. Of the many existing studies, it is found that the largest percentage in the population of each study has a visual learning style, so the learning style results in this study will be divided into dummy data where the value of 1 is for visual learning styles, and the value of 0 is for the style - non-visual learning (combined auditory and kinesthetic). In the variable of parental occupation, what is meant in this study is the job owned by the student's father or guardian. By adjusting the existing conditions in Indonesia, parents' work in this study will use dummy data. The score of 1 for parents who work as civil servants and a value of 0 for parents who work not as civil servants.

\section{METHOD}

This type of research is post-facto. Where the data in the study were obtained from data on events that had taken place, and the researcher did not manipulate or treat the existing variables. In other words, researchers collect facts through measurements so that researchers only reveal facts based on the symptoms that exist in respondents. Simultaneously, the research model is causalassociative, explaining the causal or causal relationship between the research variables. The type of research approach used is quantitative. The research was conducted from March to April in SMA Kota Magelang, which consisted of five public high schools and seven private high schools. The population in this study were all students of class XI IPS in Magelang City. Of the 12 schools, it is known that the number of class XI IPS students in Magelang City for the 2015/2016 academic year 
is 771 students. At the same time, the sample in this study was 277 students. Sampling was done using the Cluster-Stratified Random Sampling technique. Cluster stratified random sampling is a sampling technique based on specific groups, arranged according to strata. This study's collections are divided into public schools and private schools, while the strata are set based on three strata: schools with high, medium, and low ranks. Of the 771 students, the population was divided into 2 clusters: public high school students and private high school students. This division contributed $73.41 \%$ of public-school students and $26.59 \%$ of private school students. From this division, it is known that the minimum sample in this study is 203 students from public high schools and 74 students from private high schools. Each of them was taken from public and private high schools with high, medium, and low ratings. So it is known that the schools that were the samples of the study were SMAN 1 Magelang, SMAN 3 Magelang, SMAN 4 Magelang, SMA Kristen 1 Magelang, SMA Tarakanita, and SMA Catholic Pendowo Magelang.

The research was conducted by distributing questionnaires to students who were the research samples. Data on multicultural attitudes, learning styles, and parents' work were obtained through questionnaires distributed to students. Meanwhile, for economic learning achievement data, it is conveyed through achievement tests. The researchers themselves conduct achievement tests. The achievement test contains several questions derived from economic subject matter that was given during the odd semester of the 2015/2016 academic year. However, before the research was conducted, the instrument was tested on several samples from the population. Each of the clusters was taken one class by one school as a trial class. The number of students used as respondents to the instrument trial was 31 students of SMAN 5 Magelang and 31 students of SMA Muhammadiyah 1 Magelang. The trial data were then processed to test the validity and reliability of the instrument. After all, instruments are declared valid and reliable; research can be carried out. Primary data that has been collected from the research results, then analyzed using multiple regression analysis techniques. The prerequisite tests carried out before carrying out multiple regression analysis are the normality test, linearity test, multicollinearity test, and heteroscedasticity test.

\section{FINDINGS AND DISCCUSIONS}

Primary data obtained by using a questionnaire that distributes to 277 respondents or students. The variables in the preliminary data consist of multicultural attitudes $\left(\mathrm{X}_{1}\right)$, learning styles with dummy visual learning style data $\left(\mathrm{X}_{2}\right)$, parents' work with dummy data of parents who work as civil servants $\left(\mathrm{X}_{3}\right)$, and economic learning achievement $(\mathrm{Y})$ of class XI IPS students. In this study, the sample consisted of 6 schools from 12 schools in the City of Magelang. The six schools were taken based on schools' status, namely public and private, and based on the level of progress of high, medium, and low education. The recapitulation of the average primary data for each school obtained can be seen in Table 1 .

Table 1. Average Primary Data for Each School

\begin{tabular}{ccccc}
\hline School Name & $\begin{array}{c}\text { Multicultural } \\
\text { Attitude }\left(X_{1}\right)\end{array}$ & $\begin{array}{c}\text { Learning } \\
\text { Style }\left(X_{2}\right)\end{array}$ & Parents' Job $\left(X_{3}\right)$ & $\begin{array}{c}\text { Learning } \\
\text { Achievement } \\
(Y)\end{array}$ \\
\hline SMAN 1 Magelang & 80,80 & 34 & 32 & 91,97 \\
SMAN 3 Magelang & 79,87 & 18 & 10 & 71,36 \\
SMAN 4 Magelang & 82,04 & 31 & 31 & 83,61 \\
SMA Kristen 1 & 79,08 & 6 & 2 & 45,70 \\
SMA Tarakanita & 78,44 & 26 & 12 & 65,56 \\
SMA Katolik Pendowo & 77,92 & 8 & 2 & 48,87 \\
\hline
\end{tabular}

From the collected data, four prerequisite tests of multiple regression analysis were carried out. The results of each of the prerequisite tests can be seen in Table 2. By looking at the prerequisite test results in Table 2, it is known that the data has met the requirements for multiple regression analysis. The results of the multiple regression analysis can be seen in Table 3 . 
Table 2. Prerequisite Test Results for Multiple Regression Analysis

\begin{tabular}{|c|c|c|c|c|c|}
\hline Prerequisite & Test & $\begin{array}{l}\text { Multicultural } \\
\text { Attitude }\left(X_{1}\right)\end{array}$ & $\begin{array}{c}\text { Learning } \\
\text { Style }\left(X_{2}\right)\end{array}$ & $\begin{array}{l}\text { Parents' } \\
\text { Job }\left(X_{3}\right)\end{array}$ & Information \\
\hline Normalitas & Sig. & \multicolumn{3}{|c|}{ Unstandardized Residual $=0,102$} & Normal \\
\hline Linearitas & Sig. & 0,245 & - & - & Linear \\
\hline Multicollinearity & $\begin{array}{c}\text { Tolerance } \\
\text { VIF }\end{array}$ & $\begin{array}{l}0,992 \\
1,008\end{array}$ & $\begin{array}{l}0,995 \\
1,005\end{array}$ & $\begin{array}{l}0,994 \\
1,006\end{array}$ & $\begin{array}{l}\text { Free from } \\
\text { Multicollinearity }\end{array}$ \\
\hline Heteroscedasticity & Sig. & 0,090 & 0,303 & 0,055 & $\begin{array}{l}\text { Free from } \\
\text { Heteroscedasticity }\end{array}$ \\
\hline
\end{tabular}

Table 3. Results of Multiple Regression Analysis

\begin{tabular}{|c|c|c|c|c|c|c|c|}
\hline \multirow{2}{*}{\multicolumn{2}{|c|}{ Variable }} & \multirow{2}{*}{ B } & \multirow{2}{*}{$\mathrm{R}^{2}$} & \multirow{2}{*}{ Adjusted $\mathrm{R}^{2}$} & \multicolumn{2}{|c|}{ Nilai F } & \multirow{2}{*}{ Sig. } \\
\hline & & & & & Count & Table & \\
\hline $\mathrm{X} 1$ & & 0,304 & & & & & 0,023 \\
\hline $\mathrm{X} 2$ & $\mathrm{Y}$ & $-0,710$ & 0,062 & 0,051 & 5,982 & 2,638 & 0,729 \\
\hline $\mathrm{X} 3$ & & 7,992 & & & & & 0,000 \\
\hline
\end{tabular}

The results of the multiple regression analysis shown in Table 3 show four findings. The first finding, partially the multicultural attitude variable, has a sig value. $0.023(<0.05)$. This value supports the existing hypothesis, namely that multicultural attitudes affect high school students' economic learning achievement in Magelang. While the B value of 0.304 indicates that when there is an increase in multicultural attitudes in high school students in Magelang City, it will increase economic learning achievement. The contribution of multicultural attitudes to students' economic learning achievement here provides a relative contribution of $26.27 \%$. These test results align with research conducted by Separsa, Lasmawan, and Suarni (2014). In their research, all three proved an effect of multicultural attitudes on learning achievement by $23.23 \%$. Every individual needs a multicultural attitude in society because almost no society is monocultural (Zamroni, 2011, p. 31). It does not only apply to the home and work environment. There are also multicultural communities in the school environment. With a multicultural environment in schools, various habits will appear carried over to the school environment. The differences in habits that each student brings to the school environment can affect the classroom and school atmosphere to affect student achievement. Therefore, the existence of multicultural attitudes possessed by students is important. According to Adams and Zou-McGovern (from Munroe \& Pearson, 2006, p. 820), multicultural attitudes are based on presumed knowledge and beliefs, the emotional ties associated with such knowledge and beliefs, and the behavioral actions displayed owing to both.

Students with a multicultural attitude in the high category can easily adapt anywhere, including in the school environment. Banks (2007, p. 26) stated that students must acquire higher levels of knowledge, understand the relationship between knowledge and action, develop a commitment to improve the world, and acquire the skills needed to participate in civic action. It is what happened in Magelang City. Most high school students in Magelang City already have high multicultural attitudes. With this high multicultural attitude, high school students in Magelang City have the awareness to respect, tolerate, and work well together while positively impacting economic learning achievement. The second finding, partially the student learning style variable with dummy visual learning style data, has a sig value. $0.729(>0.05)$. This value does not support the research hypothesis, namely that the visual learning style affects high school students' economic learning achievement in the city of Magelang. These high school students' visual learning styles in Magelang City do not affect economic learning achievement. These test results align with Marrison and Frick's (1994) research from Purdue University, United States. Marrison and Frick did not find a significant effect of learning styles on student achievement in their research. According to him, this can happen because of the development of multimedia technology used in learning achievement tests so quickly that it can affect this study's results. Learning style is the way someone has in carrying out the learning process. The different characters possessed by students can create different learning styles 
from one another. Slavin (2011, p. 164) stated that every student has different learning styles from one another. The learning styles of high school students in the city of Magelang also differ. Of the 277 public and private high school students in Magelang, 123 students tend towards visual learning styles. In contrast, the remaining 154 students have non-visual tendencies (auditory and kinesthetic).

Most of them found that most students' learning style is also visual in existing research. As in thTheh conducted by Tanta (2010) and Gilakjani (2012) found the influence of learning styles on student achievement. Both found that most students who have high learning achievement have a visual learning style. However, this applies the opposite to high school students in the city of Magelang. The obstacle that occurs in high school students in Magelang City is that many students have not recognized their learning styles so that their learning habits do not support their learning styles. In addition, the learning process carried out is also an impostor affecting student achievement. Often, there is a mismatch between students' learning styles and the teacher's teaching styles in class. The average economy teacher in the city of Magelang teaches by using the lecture and discussion method. Economics teachers in the city of Magelang still teach without considering the learning styles that students have. Whereas, according to Suyanto and Jihad (2013, p. 53), teachers should know each student's learning styles and use teaching styles that are in accordance with student learning styles. The same opinion is followed by Fernandez (2014, p. 15), knowing our students is crucial in the teaching-learning process. With our students' knowledge, we can at least teach how best to respond to their learning style. These two things cause the student's visual learning style not to affect economic learning achievement. The third finding is that part of parents' work with dummy data of parents who work as civil servants have a sig value. $0,000(<0.05)$. This value supports the existing research hypothesis; namely, parents' work affects high school students' economic learning achievement in Magelang City.

Meanwhile, the B value of 7,992 indicates that students who have parents who work as civil servants have higher achievement than students whose parents work not civil servants. Suppose there is an increase in students with parents who work as civil servants by $1 \%$. In that case, it will increase the economic learning achievement of high school students in Magelang by $7.992 \%$. The contribution of parents who work as civil servants here gives a relative contribution of $72.55 \%$. The results of this test are in line with research conducted by Hassan (2009) in Norway, by Akinsanya, Ajayi, and Salomi (2011) in Nigeria, and research conducted by Suleman, Aslam, Hussain, Shakir, and Zaibun-nisa (2012) in Pakistan. The three studies prove that there is a significant effect of parents' work on student achievement. Work can be defined as daily activities to sustain life to obtain a better standard of living. According to Van Vuuren (1991, p. 10), work is a status in our society measured by money and measured by what we do. Jobs can classify a person into a higher or lower social group regardless of how much money is made from the job. Likewise, what happened in the city of Magelang. Of the 277 students who became respondents, only 89 students have parents who work as civil servants. It has become the view of the people in Indonesia that a job as a civil servant has a position that is considered higher than working not as a civil servant even though the money earned by working as a civil servant is sometimes not more than working not as a civil servant.

However, by working as a civil servant, the income earned will be more stable than working in other fields. This causes parents who work as civil servants to have the ability to provide adequate learning facilities for their children. These adequate learning facilities can be a driving force in improving high school students' economic achievement in the City of Magelang. The fourth finding, simultaneously multicultural attitudes, learning styles, and parents' jobs, have F count 5.982 ( $>\mathrm{F}$ table 2,638). This value supports the research hypothesis: simultaneously, multicultural attitudes, learning styles, and parents' jobs affect the economic learning high school students' achievement of high school students. The R square value of 0.051 (5.1\%) indicates the magnitude of the three independent variables' contribution in influencing the economic learning achievement of high school students in Magelang City. Learning achievement is the level of student achievement in studying science. Learning achievement is also commonly used as an indicator of the quality of knowledge that students have mastered. Therefore, when student learning achievement is low, the teacher should immediately conduct an evaluation. The evaluation was carried out to determine the Cato students' low learning achievement. 
Three factors influence student achievement, namely, internal factors, external factors, and learning approach factors. In this study, learning achievement also looked at these three factors, namely internal factors by looking at students 'multicultural attitudes and external factors by looking at students' parents and learning approach factors by looking at students' learning styles. Therefore, when these three factors examine together, it is proven to affect students' achievement in Magelang. The three variables (multicultural attitudes, learning styles, and parents' jobs) are only three of the many factors that can affect the economic learning achievement of high school students in the city of Magelang. Many other factors were not examined in this study that could affect student achievement to influence multicultural att. The styles and parents' work only affects $5.1 \%$.

\section{CONCLUSION}

Based on the tests that have been done, it can be concluded: First, there is a positive influence from multicultural attitudes on high school students' economic learning achievement in Magelang. It is indicated by the $t$ value of $2.279(>1.969)$ and a significance value of $0.023(<0.05)$. So it can be interpreted that the higher the multicultural attitude, the higher their economic learning achievement will be. Likewise, the lower the students' multicultural perspective, the lower the financial learning achievement they have. Second, there is no influence of learning styles on high school students' economic achievement in Magelang. It is indicated by the $t$ value of $-0.347(<1.969)$ and a significance value of $0.729(>0.05)$. So it can be interpreted that students' learning styles, both visual and non-visual, will not affect students' economic learning achievement. Third, there is a positive influence on parents' work on high school students' financial learning achievement in Magelang. It is indicated by the $t$ value of $3.667(>1.969)$ and a significance value of $0.000(<0.05)$. So it can be interpreted that the more students whose parents work as civil servants, the higher the economic achievement of high school students in Magelang. Likewise, the fewer students who have parents working as state employees, the lower the economic achievement of high school students in Magelang.

Fourth, collectively, there is a positive influence from multicultural attitudes, learning styles, and parents' jobs on high school students' economic learning achievement in Magelang. It is indicated by the calculated $\mathrm{F}$ value of $5.982(>2.638)$ and a significance value of $0.001(<0.05)$. The implications are: 1.) A high multicultural attitude will affect students' economic learning achievement. The diversity that exists in the school environment will require students to recognize and appreciate this diversity. Having an attitude of mutual awareness and respect for diversity will foster tolerance and good cooperation between students. That sense of patience and collaboration creates intimacy so that students have an enthusiasm for learning. With high confidence for knowledge, it will result in high learning achievement as well; 2.) Learning styles alone are not sufficiently proven to affect student achievement. It also requires teachers' feedback in schools to adjust students' teaching styles and learning styles. The absence of a match between student learning styles and teaching styles maintained by teachers unconsciously creates an environment that is less comfortable and conducive, both for students and teachers. When in class there is a match between learning styles and teaching styles, it will encourage creating an environment conducive to teaching and learning activities to affect teaching and learning success as seen through students' learning achievements. Regardless of whether there is a match between learning and teaching styles, by looking at existing theories and research, most of them state that learning styles significantly affect learning achievement. It contradicts the results in this study, so further research is needed to prove whether there is an effect of learning techniques on student achievement; and 3.) Parents 'occupation is proven to affect students' economic learning achievement. Students who have parents who work as civil servants tend to get special attention from parents regarding education, from learning facilities to psychological support. It can occur because the income owned by civil servants tends to be more specific and more routine than that of parents who work not as civil servants. With an individual and regular income, parents who work as civil servants can give their children special attention by providing adequate learning facilities. The existence of proper teaching facilities will foster high learning motivation in children to obtain high learning achievement. 


\section{REFERENCES}

Abosede, S. C. (2015). Gender, parents' job-type and family size as determinants of junior secondary school students' academic performance. International Journal of Humanities and Social Science, 5(4), 75-81. Retrieved from http://citeseerx.ist.psu.edu/viewdoc/download?doi=10.1.1.1050.9701\&rep=rep1\&type=pdf

Arshad, M., Shahzadi, E., \& Mahmood, A. (2016). Parents involvement at university level education: Students perception in under developing country. European Scientific Journal, 12(22), 294 304. doi: http://dx.doi.org/10.19044/esj.2016.v12n22p294

Banks, A. (2007). Educating citizens in a multicultural society. New York: Teacher College University.

Banks, A. (2009). The routledge international companion to multicultural education. New York: Routledge.

Bernal, A., Urpí, C., Rivas, S., \& Repáraz, R. (2011). Social values and authority in education: Collaboration between school and families. NASPA Journal About Woman in Higher Education, 5(2), 134-143. Retrieved from https://pdfs.semanticscholar.org/651b/f270e3142b1b76cbbb5c9a6344325e0cf356.pdf

Berns, R. M. (2010). Child, family, school, community: Socialization and support eight edition. California: Wadsworth.

Billings, G. L., \& Gillborns, D. (2004). Multicultural education. London: Routledge Falmer.

Braster, S., \& Dronkers, J. (2013). The positive effects of ethnic diversity in class on the educational performance of pupils in a multi-ethnic European metropole. London: Centre for Research and Analysis of Migration.

Cruickshank. D. R., Jenkins, D. B., \& Metcalf, K. K. (2014). The act of teaching (6 $6^{\text {th }}$ ed.). (G. T. Pratiwi, Trans.). Jakarta: Salemba Humanika.

Dronkers, J., Van der Velden, R., \& Dunne, A. (2012). Why are migrant students better off in certain types of educational systems or schools than in others?. European Educational Research Journal, 11(1), 11-44. doi: https://doi.org/10.2304/eerj.2012.11.1.11

Dusi, P. (2020). The family-school relationship in primary education. Parents' perspectives in the age of "the minimal self". International Journal About Parents in Education, 12(1), 13-25. Retrieved from http://www.ernape.net/ejournal/index.php/IJPE/article/view/369

Fernandez, E. S. (2014). Teaching for a culturally diverse and racially just word. Eugene: Wipf and stock publishers.

Gilakjani, A. P. (2012). Visual, auditory, kinaesthetic learning styles and their impacts on English language teaching. Journal of studies in education, 2(1), 104-113. doi: http://dx.doi.org/10.5296/jse.v2i1.1007

Gu, H., Yin, L., \& Li, J. (2015). Making homework a catalyst of teacher-parents-children's collaboration: A teacher research study from an elementary school in China. International Journal about Parents in Education, 9(1), 47-65. Retrieved from http://www.ernape.net/ejournal/index.php/IJPE/article/viewFile/308/239

Hamalik, O. (2013). Kurikulum dan pembelajaran. Jakarta: Bumi Aksara.

Hassan, J. E. (2009). Parents' socioeconomic status and children's academic performance. Report of Norwegian Social Research, NOVA Notat, 7(09), 1-60. Retrieved from https://fagarkivet.oslomet.no/bitstream/handle/20.500.12199/5214/3827 1.pdf?sequence=1 \&isAllowed $=\mathrm{y}$

Knowles, G., \& Lander, V. (2011). Diversity, equality and achievement in education. Chennai: C \& $M$ Digitals (P) Ltd. 
Marrison, D. L., \& Frick, M. J. (1994). The effect of agricultural student' learning styles on academic achievement and their perceptions of two methods of instruction. Journal of Agricultural Education, 35 (1), 26-30.

Marrison, D. L., \& Frick, M. J. (1994). The effect of agricultural students' learning styles on academic achievement and their perceptions of two methods of instruction. Journal of Agricultural Education, 35(1), 26-30. Retrieved from https://www.researchgate.net/profile/Martin Frick2/publication/238521723 The Effect O f_Agricultural_Students'_Learning_Styles_On_Academic_Achievement_And_Their_Perce ptions_Of_Two_Methods_Of_Instruction/links/004635304f0584caf4000000.pdf

Maruyama, G., Moreno, J. F., Gudeman, R. H., \& Marin, P. (2000). Does diversity make a difference?: Three research studies on diversity in college classrooms. Washington DC: American Council on Education - American Association of University professors.

Mendel, M. (2020). Education is power and parents are force. International Journal about Parents in Education, 12(1), 1-7. Retrieved from http://www.ernape.net/ejournal/index.php/IJPE/article/view/367/275

Munroe, A., \& Pearson, C. (2006). The munroe multicultural attitude scale questionnaire: A new instrument for multicultural studies. Educational and Psychological Measurement, 66(5), 819-834. doi: https://doi.org/10.1177/0013164405285542

Parekh, B. (2000). Rethinking multiculturalism: cultural diversity and political theory. London: Macmillan Press Ltd.

Separsa, A. A. G. A., Lasmawan, I. W., \& Suarni, N. K. (2014). Pengaruh implementasi teknik klarifikasi nilai terhadap prestasi belajar PKN dengan kovariabel sikap multikultur pada siswa kelas VIII SMP Negeri 1 Payangan. Jurnal Penelitian dan Evaluasi Pendidikan Indonesia, 4(1). Retrieved from http://119.252.161.254/ejournal/index.php/jurnal_ep/article/view/1175

Slameto, S. (2013). Belajar dan faktor-faktor yang mempengaruhinya. Jakarta: Rineka Cipta.

Slavin, R. E. (2011). Educational psychology: Theori and practice $\left(9^{\text {th }}\right.$ ed). (M. Samosir, Trans.). Jakarta: Indeks.

Suleman, Q., Aslam, H. D., Hussain, I., Shakir, M., \& Zain-un-Nisa, Z. (2012). Effects of parental socioeconomic status on the academic achievement of secondary school students in Karak district Pakistan. International Journal of Human Resources Studies, 2(4), 14-31. doi: http://dx.doi.org/10.5296/ijhrs.v2i4.2511

Suyanto, S., \& Jihad. A. (2013). Menjadi guru profesional. Bandung: Erlangga.

Syah, M. (2013). Psikologi pendidikan dengan pendekatan baru. Bandung: PT. Remaja Rosdakarya.

Tanta, T. (2010). Pengaruh gaya belajar terhadap hasil belajar mahasiswa pada mata kuliah biologi umum Program Studi Pendidikan Biologi Universitas Cendrawasih. Jurnal Kreatif: Jurnal Kependidikan Dasar, 1(1), 7-21. doi: https://doi.org/10.15294/kreatif.vli1.1666

Van Vuuren, N. (1991). Work and career: Manage work outside and within the home. (A. G. Lurandi, Trans.). Yogyakarta: Kanisius.

Zamroni, Z. (2011). Pendidikan demokrasi pada masyarakat multikultural. Yogyakarta: Gavin Kalam Utama. 